\title{
Climatic Impact on Small Grain Production in the Subarctic Region of the United States
}

\author{
B.S. SHARRATT, ${ }^{1}$ C.W. KNIGHT ${ }^{2}$ and F. WOODING ${ }^{2,3}$
}

(Received 5 July 2002; accepted in revised form 24 October 2002)

\begin{abstract}
The Subarctic comprises the higher mid-latitudinal regions with short, cool, moist summers and long, cold, dry winters. Indeed, the short, cool growing season is often thought of as a barrier to crop growth and diversity in these regions. Little is known, however, concerning the impact of the Subarctic climate on crop production. This study aimed to identify the climatic factors that are most important to the production of small grains in the Subarctic region of Alaska. The impact of climate on 'Galt' and 'Weal' barley (Hordeum vulgare L.), 'Nip' and 'Toral' oat (Avena sativa L.), and 'Gasser' and 'Park' wheat (Triticum aestivum L.) was assessed using climate and grain yield data collected from 1972 to 1989 at Fairbanks. Multiple regression analysis was used to identify the climatic factors that most influence yield. Different factors accounted for the largest proportion of variability in yield across years for the different grains. 1) For barley, variations in precipitation deficit (pan evaporation minus precipitation) and distribution of precipitation events within a growing season accounted for $41 \%$ of the variability across years in yield of Galt and Weal cultivars. 2) For oat, variations in the precipitation deficit ratio (ratio between precipitation deficit and pan evaporation) accounted for $44 \%$ of the variability across years in yield of Nip and 58\% in yield of Toral oat. 3) For wheat, variations in number of days between precipitation events within a growing season, precipitation deficit, and temperature explained $70 \%$ of the variability across years in yield of Gasser and Park wheat. Results from our analysis further indicated that small grain production was bolstered in seasons with greater precipitation, more frequent precipitation, or lower evaporative demand (pan evaporation). Only wheat production appeared to be favored by higher minimum air temperatures. This study suggests that, despite the cool growing season in interior Alaska, the primary climatic limitation to crop production is water stress, associated with low precipitation or high evaporative demand. Therefore, land management practices aimed at conserving soil water will likely bolster crop production in the Subarctic.
\end{abstract}

Key words: barley, oat, wheat, cereals, grain yield, Alaska, climate

RÉSUMÉ. Le Subarctique comprend l'extrême nord des latitudes moyennes où les étés sont courts, frais et humides et les hivers longs, froids et secs. En fait, on pense souvent que la brièveté et la fraîcheur de la saison de croissance sont des obstacles au développement et à la diversité des cultures dans ces régions. En revanche, on sait très peu de choses sur l'impact qu'a le climat subarctique sur la production végétale. Cette étude vise à déterminer les facteurs climatiques les plus importants pour la production des petites céréales dans la zone subarctique de l'Alaska. On a mesuré l'incidence du climat sur l'orge (Hordeum vulgare L.) «Galt» et «Weal», l'avoine (Avena sativa L.) «Nip» et «Toral» et le blé (Triticum aestivum L.) «Gasser» et «Park» en se servant de données sur le climat et le rendement recueillies à Fairbanks de 1972 à 1989. On a eu recours à l'analyse de régression multiple pour mettre en évidence les facteurs climatiques qui ont la plus grande influence sur le rendement. Au cours de toutes les années, la majeure partie de la variabilité dans le rendement des différentes céréales s'expliquait par plusieurs facteurs: 1) Pour l'orge, les variations dans le déficit de précipitations (évaporation du bac moins les précipitations) et la distribution des événements hyétométriques durant une saison de croissance comptaient pour $41 \%$ de la variabilité au cours des années dans le rendement des cultivars Galt et Weal; 2) Pour l'avoine, les variations dans le rapport du déficit de précipitations (rapport entre le déficit de précipitations et l'évaporation du bac) comptaient pour $44 \%$ de la variabilité au cours des années dans le rendement de l'avoine Nip et $58 \%$ dans celui de l'avoine Toral; 3) Pour le blé, les variations du nombre de jours entre les événements hyétométriques dans le cadre d'une saison de croissance, du déficit de précipitations et de la température expliquaient $70 \%$ de la variabilité au cours des années dans le rendement du blé Gasser et Park. Les résultats de notre analyse indiquent en outre que la production des petites céréales a été favorisée durant les saisons où les précipitations étaient plus abondantes, plus fréquentes, ou encore où la demande d'évaporation (évaporation du bac) était plus faible. Seule la production de blé semblait bénéficier de températures ambiantes minimales plus élevées. Cette étude suggère que, malgré la fraîcheur et la brièveté de la saison de croissance dans l'intérieur de l'Alaska, le facteur climatique primaire qui limite la production végétale est le stress hydrique, joint à de faibles précipitations ou à une forte demande d'évaporation. Par conséquent, les pratiques de gestion des terres qui visent à conserver l'eau du sol favoriseront très probablement la production végétale dans le Subarctique.

\footnotetext{
${ }^{1}$ USDA-Agricultural Research Service, Land Management and Water Conservation Research Unit, 215 Johnson Hall, Washington State University, Pullman, Washington 99164, U.S.A.; sharratt@wsu.edu

${ }^{2}$ School of Agriculture and Land Resource Management, University of Alaska, Fairbanks, Alaska 99775, U.S.A.

${ }^{3}$ Deceased.

(C) The Arctic Institute of North America
} 
Mots clés: orge, avoine, blé, céréales, rendement céréalier, Alaska, climat

Traduit pour la revue Arctic par Nésida Loyer.

\section{INTRODUCTION}

The Subarctic comprises higher mid-latitudinal regions $\left(50^{\circ}\right.$ to $\left.70^{\circ} \mathrm{N}\right)$ of North America and Eurasia with short, cool, moist summers and long, cold, dry winters (Gabler et al., 1999). The climate of the Subarctic varies across regions and is generally considered suboptimal for producing a wide array of agricultural crops. Spring grain and oilseed crops such as corn and sunflower often fail to mature during the short and cool growing season. Indeed, the occurrence of frost in late spring frequently hinders early establishment of crops, while frost in late summer typically halts grain maturation. Winter crops such as winter wheat are not well adapted to the Subarctic because of poor winter survival associated with low-temperature injury, desiccation, and disease (Wooding and McBeath, 1984). Therefore, short, cool growing seasons and cold winters are often thought of as barriers to crop growth and diversification in the Subarctic.

Crop adaptation and production in the Subarctic region of the United States have been examined since 1898, when the first agricultural experiment stations were established in Alaska (Wooding, 1998). Research at these experiment stations in the early 1900s was aimed toward selecting cereal crops capable of maturing and producing seed in harsh environments. In the late 1960s, the discovery of petroleum in Alaska marked a new era for agriculture in the state. The resulting economic boom provided the wealth necessary to support the development of renewable resource industries throughout the state (Lewis and Pearson, 1998). As part of this development, large tracts of land suitable for crop production were cleared of forest in the interior region of Alaska (Epps and Kern, 1983). An important part of developing agriculture in the state involved initiating research to create new cultivars of small grains (Taylor, 1983).

Although small grain crops are readily grown in the Subarctic, little is known concerning the impact of climate on grain production in interior Alaska. Previous studies identified the superficial impacts of climate on growth and production in Alaska. For example, Allen (1983) characterized interior Alaska as a region with a short and cool growing season, susceptible to frost during any month of summer, and with marginal and poorly distributed precipitation. He suggested that these factors could limit the expansion of agriculture enterprises in some areas of interior Alaska, but made no attempt to relate these climatic factors to crop production. Sharratt $(1994,1998)$ found that water stress occurs frequently in interior Alaska and therefore depresses yield of barley. Other climatic factors affecting yield were not considered in these studies. Knight et al. (1978) assessed the potential for wheat production in various regions of Alaska on the basis of air temperature.
They believed production would be favored in regions where the mean maximum air temperature during July was at least $22^{\circ} \mathrm{C}$ (east-central Alaska) and would be poor in regions where the maximum July air temperature was less than $19^{\circ} \mathrm{C}$ (coastal and northern Alaska).

In Subarctic regions of Eurasia, precipitation appears to be the most important climatic factor affecting small grain production. Precipitation is the primary climatic factor influencing wheat production in western Siberia, where inadequate or poorly distributed rain during summer suppresses yield (Moshchenko and Zagrebel'nyy, 1984; Vaganov, 1990). Precipitation also appears to influence production in Scandinavia. For example, Kontturi (1979) identified inadequate precipitation as the primary climatic factor causing poor yield of wheat at about $60^{\circ} \mathrm{N}$ latitude in southern Finland. Nurminiemi and Rognli (1996) also found that drought in the early stages of plant development caused poor yield of barley at $60^{\circ} \mathrm{N}$ latitude (southern Norway and Finland); at more southerly latitudes $\left(56^{\circ} \mathrm{N}\right.$, in Denmark and southern Sweden), however, cool and rainy growing seasons suppressed yield. The contrasting results between these latitudinal regions of Scandinavia reflect a gradation in climate types; the southern regions are subject to a more maritime, rather than continental, climate. Peltonen et al. (1990) reported that air temperatures were a better determinant than precipitation or global radiation of spring wheat yield in southern Finland $\left(60^{\circ} \mathrm{N}\right)$, but their study appeared to be confounded by differences in the cultivars grown each year.

Previous studies suggest that precipitation may be the primary climatic factor causing interannual variation in yield of small grain crops in the Subarctic. These studies, however, are few and are largely confined to Eurasia. Application of these results to other regions of the world is difficult because of the diversity in weather patterns (macroand mesoscale features) that exist across the Subarctic. Yet, the influence of climate on production must be understood in order to improve cropping systems within specific regions of the Subarctic. Studies of climatic influence could aid in developing new cultivars capable of withstanding climatic stress, assessing the need for supplemental management practices (e.g., irrigation), and identifying new regions with a climate suitable for crop production. The purpose of this study was to identify those climatic factors most important to the production of small grains in the interior region of Alaska.

\section{METHODS}

The impact of the Subarctic climate on small grain production was assessed by acquiring grain yield and 
climate data in Alaska. Yield and climate data were collected over several years at the Agricultural Experiment Station located on the University of Alaska campus in Fairbanks. The Fairbanks area is characterized by a frostfree period (the time between the last killing frost in spring and the first killing frost in autumn) of 90 days and annual precipitation of $300 \mathrm{~mm}$.

\section{Agronomy}

Yield data were acquired from small grain variety trials conducted at the University Experiment Station $\left(64^{\circ} 51^{\prime} \mathrm{N}\right.$, $147^{\circ} 52^{\prime} \mathrm{W}$ ) from 1972 to 1989 . Yield data were not available (no information was found) from 1976, 1977, and 1979. Cultivars were grown in a Randomized Complete Block experimental design with three replications. Individual plots were $3 \times 1.5 \mathrm{~m}$. The trials were terminated in 1989 because of program changes at the University of Alaska, and little progress has been made in breeding and selecting for new cultivars of small grains in Alaska since then. In fact, no cultivars of wheat or oat have been released in Alaska since 1981. Finaska barley was released in 2001 (Dofing and Knight, 2001), but quantities are not yet sufficient to make it available to producers in the state.

Yield-climate analyses were performed on Galt and Weal barley, Nip and Toral oat, and Gasser and Park wheat. These cultivars were used as standards of comparison in all trials conducted in Alaska from 1972 to 1989. Galt is a medium-maturing barley (1972-89 data indicate that it requires about 90 days to mature) developed in Alberta, Canada. With an average grain yield of about $4800 \mathrm{~kg} \mathrm{ha}^{-1}$ from 1972 to 1989 , Galt is one of the most productive cultivars tested in Alaska, but it fails to mature during the short growing season, and the authors are not aware of any currently being grown commercially. Weal, an early-maturing barley (ca. 85 days) developed in Alaska and currently grown there for forage, is typically less productive (ca. $4200 \mathrm{~kg} \mathrm{ha}^{-1}$ ) than Galt. Nip is a very earlymaturing oat (ca. 95 days) of Swedish origin. Toral is an early-maturing oat (100 days) developed in Alaska and is typically more productive than Nip (ca. $4500 \mathrm{~kg} \mathrm{ha}^{-1}$ for Toral vs. $4000 \mathrm{~kg} \mathrm{ha}^{-1}$ for Nip). Like Toral, however, Nip is a popular cultivar currently grown for both commercial grain and forage production in Alaska. Gasser and Park are early-maturing wheat cultivars (both require ca. 100 days to mature), the former developed in Alaska and the latter developed in Alberta, Canada. Park is one of the most productive cultivars (ca. $4000 \mathrm{~kg} \mathrm{ha}^{-1}$ ) tested in Alaska. Gasser, while less productive than Park (ca. $3500 \mathrm{~kg} \mathrm{ha}^{-1}$ ), is superior in milling qualities to other cultivars tested in Alaska. Little wheat is currently grown commercially in Alaska, however, because of its failure to mature during the short growing season or the high moisture content of the grain at the time of harvest.

Barley, oat, and wheat were sown at a depth of $35 \mathrm{~mm}$ in rows spaced $180 \mathrm{~mm}$ apart in early to mid-May (dates across years varied from 5 May to 20 May) on a nearly level Tanana silt loam. The soil was formed from alluvial deposits several meters in thickness. Sowing rate was $80 \mathrm{~kg}$ $\mathrm{ha}^{-1}$ for barley, $100 \mathrm{~kg} \mathrm{ha}^{-1}$ for wheat, and $110 \mathrm{~kg} \mathrm{ha}^{-1}$ for oat. Fertilizer was broadcast and incorporated prior to sowing according to soil fertilizer recommendations. Plots were hand-harvested at the kernel ripe stage of development (harvest across years varied from 25 July to 15 August for barley and from 5 August to 30 August for oat and wheat). Harvested samples were air-dried before threshing; grain was then oven-dried at $60^{\circ} \mathrm{C}$ until weight remained constant over 24 hours.

\section{Climate}

Climatic data were assessed over seasonal and monthly (June and July) periods in this study. The months of June and July closely coincide with the major periods of development of small grains in interior Alaska. Tillering and stem extension occur during June. Heads emerge from leaf collars beginning in early July, and flowering commences within days after head emergence. Kernels fill and ripen from mid-July to early August.

Daily maximum and minimum air temperature, precipitation, and pan evaporation data were obtained from NOAA climatological data for the University Experiment Station $\left(64^{\circ} 51^{\prime} \mathrm{N}, 147^{\circ} 52^{\prime} \mathrm{W}\right.$; elevation $145 \mathrm{~m}$ above mean sea level). The climatological observatory was located $200 \mathrm{~m}$ from the variety trial plots. Missing temperature and precipitation data were obtained from records of the Fairbanks Weather Service Field Office $\left(64^{\circ} 49^{\prime} \mathrm{N}, 147^{\circ} 52^{\prime} \mathrm{W}\right.$, elevation $135 \mathrm{~m}$ ) located $5 \mathrm{~km}$ from the University Experiment Station. Missing pan evaporation data were estimated using the Blaney-Criddle equation (Jensen et al., 1990), which computes potential evapotranspiration (PET) from readily available temperature data. Comparisons between pan evaporation and PET indicated that the Blaney-Criddle equation overestimated daily pan evaporation by $20 \%$ or more, particularly on days with low evaporative demand. Therefore, PET was adjusted on the basis of a linear relationship (with a standard error of estimate of $0.1 \mathrm{~cm}$ ) between pan evaporation and PET.

Climatic factors important to plant growth and considered in this study are shown in Table 1. These factors were derived from temperature, precipitation, and pan evaporation (PE) data. Days and cumulative PE between daily precipitation events of $0.75 \mathrm{~cm}$ were considered in this analysis, as these events are needed to balance maximum daily PE. Precipitation deficit (PD) was defined as PE minus precipitation, while the precipitation deficit ratio (PDR) was defined as the ratio of PD to PE. Winter precipitation included precipitation received from autumn to spring (September 1 to day of sowing) and was used as an index of soil water available at the beginning of the growing season. Insolation was computed using the method of Bristow and Campbell (1984). This method, which relies in part on the measured range in diurnal air temperature, has been used with success at latitudes well beyond 
those of its origin (Goodin et al., 1999; Donatelli and Bellocchi, 2000).

\section{Yield-Climate Analysis}

Multiple regression analysis was used to identify those seasonal and monthly climatic factors that largely contributed to the variability in yield across years. In the event that climatic factors were collinear, only one factor was included in the analysis. Those factors exhibiting collinearity included: 1) Mean daily air temperature and mean maximum or mean minimum daily air temperature, 2) precipitation, days with precipitation, PD, and PDR, 3) PD, PDR, storage precipitation deficit, and storage precipitation deficit ratio, 4) storage precipitation deficit, storage precipitation deficit ratio, and winter precipitation, and 5) maximum number of days between precipitation events, standard deviation of the number of days between precipitation events, maximum cumulative PE between precipitation events, and standard deviation of the cumulative PE between precipitation events. All parameters with significant $(p \leq 0.05)$ coefficients were identified using backward selection techniques (Lund, 1989) as a means to elucidate those factors exerting most influence on yield variation of both cultivars. The expected sign of the significant parameters and adjusted $\mathrm{R}^{2}$ were used to select the equation that best described yield variation.

\section{RESULTS AND DISCUSSION}

Interannual variation in yield of crops grown at the same physical location using identical management practices provides insight into the dynamic effect of climate on crop production. This dynamic interaction between small grain production and climate in interior Alaska is illustrated in Figure 1. The variation in yield depicted in this figure, however, may not be entirely related to climate. Other factors that may have influenced crop yield, such as pests and lodging, could not be documented in this study.

Interannual variation in yield was nearly the same for Galt and Weal barley. The standard deviation in yield across seasons was $1215 \mathrm{~kg} \mathrm{ha}^{-1}$ for Galt barley and 1180 $\mathrm{kg} \mathrm{ha}^{-1}$ for Weal barley. Yield of Galt barley, however, was greater: averaged across seasons, Galt barley produced $600 \mathrm{~kg} \mathrm{ha}^{-1}$ more grain than Weal barley. Toral oat was more sensitive to yearly climatic variations than Nip oat, as evidenced by the higher standard deviation in yield (1520 kg ha-1 for Toral oat vs. $1130 \mathrm{~kg} \mathrm{ha}^{-1}$ for Nip oat). Toral oat also produced $550 \mathrm{~kg} \mathrm{ha}^{-1}$ more grain than Nip oat. Park wheat appeared to be more responsive to seasonal climatic fluctuations than Gasser wheat, as substantiated by the higher standard deviation in yield $\left(990 \mathrm{~kg} \mathrm{ha}^{-1}\right.$ for Park wheat vs. $830 \mathrm{~kg} \mathrm{ha}^{-1}$ for Gasser wheat.) Averaged across years, Park wheat produced $500 \mathrm{~kg} \mathrm{ha}^{-1}$ more grain than did Gasser wheat.
Yield and Climate Extremes

Barley: Yield of barley, averaged across cultivars, varied from $2745 \mathrm{~kg} \mathrm{ha}^{-1}$ in 1986 to $6785 \mathrm{~kg} \mathrm{ha}^{-1}$ in 1980 (Fig. 1). Yield was depressed in 1986, probably as a result of an extended drought during the season. Cumulative pan evaporation (PE) escalated to $29.8 \mathrm{~cm}$ over a 71-day period (sowing to 19 July 1986) when no rainfall event of $0.75 \mathrm{~cm}$ or more occurred. In addition, growth and production may have been repressed in 1986 by the lowest insolation (21.2 $\mathrm{MJ} \mathrm{d}^{-1}$ ) of any year in this study (insolation ranged from 21.2 to $25.6 \mathrm{MJ} \mathrm{d}^{-1}$ across years). In 1980 , more favorable temperatures and low water stress likely contributed to the greatest yield. Seasonal minimum air temperature $\left(6.0^{\circ} \mathrm{C}\right)$ and precipitation deficit ratio $(0.64)$ ranked lower in 1980 than in any other year of this study.

Oat: Yield of oat, averaged across cultivars, varied from $2130 \mathrm{~kg} \mathrm{ha}^{-1}$ in 1974 to $6470 \mathrm{~kg} \mathrm{ha}^{-1}$ in 1982 . The small yield in 1974 was associated with the fewest number of days (21) with precipitation during a growing season and the greatest precipitation deficit $(36.0 \mathrm{~cm})$ during the 15 -year record. Days with precipitation varied from 21 to 50 , while precipitation deficit varied from 22.6 to $36.0 \mathrm{~cm}$ over the 15 seasons. The supreme yield in 1982 may have been attained in response to more favorable temperatures and precipitation. The seasonal minimum air temperature was lowest (ranged from $6.1^{\circ}$ to $9.1^{\circ} \mathrm{C}$ ), precipitation was greatest (ranged from 6.6 to $22.2 \mathrm{~cm}$ ), and precipitation deficit was smallest (ranged from 22.6 to $36.0 \mathrm{~cm}$ ) in 1982 as compared with other years in this study.

Wheat: Yield of wheat, averaged across cultivars, ranged from $1940 \mathrm{~kg} \mathrm{ha}^{-1}$ in 1974 to $5075 \mathrm{~kg} \mathrm{ha}^{-1}$ in 1982 . Like oat, wheat had its smallest yield in 1974, which was associated with the fewest number of days (18) with precipitation during a growing season. Days with precipitation ranged from 18 to 50 over the 15-year record. Yield of wheat was likely bolstered in 1982 by more favorable precipitation. Indeed, seasonal precipitation was greater (ranged from 6.6 to $22.2 \mathrm{~cm}$ ) and the precipitation deficit smaller (ranged from 22.6 to $35.0 \mathrm{~cm}$ ) in 1982 than in any other year of this study.

\section{Yield-Climate Analysis}

Crops in the Subarctic are susceptible to a killing frost any time during the growing season. For this reason, growing crops is a venture; plant grow th and development may be terminated when vegetative or reproductive tissue is exposed to lethal temperatures. Indeed, Jakovlev (1973) noted that yield of spring wheat in the northern regions of Russia is often depressed by the occurrence of a killing frost during maturation. In this study, a killing frost (daily minimum air temperature of $-2.2^{\circ} \mathrm{C}$ or lower) occurred during 7 of the 15 growing seasons (Table 1). In 1975, 1980, and 1989, frost occurred soon after sowing (within 10 days) and likely had little influence on plant growth, since the appearance of the first full leaf requires about 125 
TABLE 1. Climatic factors considered in the analysis of the variation in yield of barley, oat, and wheat from 1972 to 1989 at Fairbanks, Alaska.

\begin{tabular}{|c|c|c|c|}
\hline Climatic Factors & Barley & Oat & Wheat \\
\hline \multicolumn{4}{|l|}{ Seasonal Temperature Factors: } \\
\hline Mean daily air temperature $\left({ }^{\circ} \mathrm{C}\right)$ & $14.3(0.7)^{1}$ & $14.2(0.7)$ & $14.2(0.7)$ \\
\hline Mean daily maximum air temperature $\left({ }^{\circ} \mathrm{C}\right)$ & $21.3(0.7)$ & $21.2(0.7)$ & $21.2(0.8)$ \\
\hline Mean daily minimum air temperature $\left({ }^{\circ} \mathrm{C}\right)$ & $7.2(0.9)$ & $7.3(0.9)$ & $7.2(1.0)$ \\
\hline Growing seasons with killing frost (\%) & 40.0 & 46.7 & 40.0 \\
\hline \multicolumn{4}{|l|}{ Seasonal Precipitation or Evaporation Factors: } \\
\hline Precipitation, or $\mathrm{P}(\mathrm{cm})$ & $10.8(3.8)$ & $12.3(3.8)$ & $12.1(3.9)$ \\
\hline Days with precipitation & $28.0(9.0)$ & $31.5(8.5)$ & $31.1(8.9)$ \\
\hline Days between precipitation events, maximum & $39.0(14.2)$ & $39.3(14.0)$ & $39.7(14.2)$ \\
\hline Days between precipitation events, standard deviation & $15.3(8.1)$ & $14.8(7.0)$ & $15.0(7.2)$ \\
\hline Winter precipitation, or WP $(\mathrm{cm})$ & $13.1(3.3)$ & $13.1(3.3)$ & $13.1(3.3)$ \\
\hline Pan evaporation, or PE $(\mathrm{cm})$ & $38.0(3.2)$ & $41.7(3.4)$ & $41.6(3.2)$ \\
\hline \multicolumn{4}{|l|}{ Factors Derived from Temperature, Precipitation, or Evaporation: } \\
\hline Cumulative PE between precipitation events, maximum (cm) & $17.4(5.8)$ & $17.5(5.8)$ & $17.6(5.8)$ \\
\hline Cumulative PE between precipitation events, standard deviation $(\mathrm{cm})$ & $7.0(3.5)$ & $6.8(3.2)$ & $6.8(3.2)$ \\
\hline Seasonal precipitation deficit, or PD: PE-P (cm) & $27.2(3.8)$ & $29.4(4.2)$ & $29.6(4.0)$ \\
\hline Seasonal precipitation deficit ratio, or PDR: (PE-P):PE & $0.716(0.093)$ & $0.706(0.084)$ & $0.711(0.086)$ \\
\hline Storage precipitation deficit, or PD: PE-WP-P (cm) & $14.1(5.7)$ & $16.3(6.2)$ & $16.5(6.1)$ \\
\hline Storage precipitation deficit ratio, or PDR: (PE-WP-P):PE & $0.367(0.136)$ & $0.388(0.130)$ & $0.392(0.129)$ \\
\hline Mean daily insolation $\left(\mathrm{MJ} \mathrm{m}^{-2}\right)$ & $23.3(1.2)$ & $22.6(1.2)$ & $22.6(1.3)$ \\
\hline
\end{tabular}

${ }^{1}$ Standard deviation in parenthesis.

thermal units (or 12 days) in interior Alaska (Dofing and Karlsson, 1993; Sharratt, 1999). In 1974, frost had little impact on crop yield, as lethal temperatures occurred after ripening of barley and wheat but two days prior to ripening of oat. Crop growth and yield, however, may have been influenced by the occurrence of a killing frost during the 1972, 1978, and 1983 seasons. Frost occurred about 20 days after sowing in 1972 and 1983 and 35 days after sowing in 1978. Therefore, the impact of frost on crop yield was assessed using the occurrence of killing frost as a categorical independent (dummy) variable in regression analysis. Our analysis, however, indicated that frost did not influence the yield of cultivars used in this study.

Barley: Seasonal climatic factors most important in accounting for the variation in yield of barley over the 15 years of record at Fairbanks included those associated with evaporative stress, namely precipitation deficit and pan evaporation. The association between yield of Galt and Weal barley and these climatic factors can be expressed as:

$$
\begin{gathered}
\text { Galt: } \text { Yield }=9930-145 \times \mathrm{PD}-169 \times \mathrm{PE}_{\mathrm{sd}} \\
\text { Weal: Yield }=9824-207 \times \mathrm{PD}
\end{gathered}
$$

where yield is in $\mathrm{kg} \mathrm{ha}^{-1}, \mathrm{PD}$ is precipitation deficit $(\mathrm{cm})$, and $\mathrm{PE}_{\mathrm{sd}}$ is the standard deviation in cumulative $\mathrm{PE}$ between precipitation events $(\mathrm{cm})$. The latter factor, $\mathrm{PE}_{\mathrm{sd}}$, was used as an index of the distribution of precipitation events during the growing season, with higher $\mathrm{PE}_{\mathrm{sd}}$ signifying more poorly distributed precipitation. These factors, $\mathrm{PD}$ and $\mathrm{PE}_{\mathrm{sd}}$, explained $41 \%$ of the variation in yield of both Galt and Weal barley. The relationships expressed by Equations 1 and 2 suggested that a decline in the PD or a more even distribution in precipitation events (smaller $\mathrm{PE}_{\mathrm{sd}}$ ) during the growing season bolstered yield of Galt and Weal barley. Slope estimates of PD were not different between cultivars and suggest that a decline of $1 \mathrm{~cm}$ in the seasonal PD (less pan evaporation or more precipitation) bolstered yield of Galt and Weal barley by about $190 \mathrm{~kg} \mathrm{ha}^{-1}$.

Climatic stresses occurring in July (during heading, flowering, and kernel formation) appeared to have more impact on yield of barley than those occurring in June (during tillering and stem extension). Indeed, frequency of precipitation in July was the only monthly climatic factor that significantly influenced yield of Galt and Weal barley. The influence of precipitation on crop production is likely accentuated in July because soil water reserves continue to decline as the growing season advances, reaching a minimum in mid- to late July (Sharratt, 1994, 1998). Yield was positively influenced by the more frequent occurrence of precipitation in July. This factor accounted for $25 \%$ of the variability in yield for Galt barley and $45 \%$ for Weal barley.

Oat: The single most important climatic factor that influenced yield of oat was the precipitation deficit ratio. This factor accounted for the largest percentage of variation in yield of Nip and Toral oat across years. The association between yield of Nip and Toral oat and precipitation deficit ratio can be expressed as:

$$
\begin{gathered}
\text { Nip: Yield }=10600-9392 \times \text { PDR } \\
\text { Toral: Yield }=14550-14178 \times \text { PDR }
\end{gathered}
$$

where PDR is the precipitation deficit ratio. This factor accounted for $44 \%$ of the yield variation in Nip oat and $58 \%$ in Toral oat. Yield of oat was bolstered in years with 


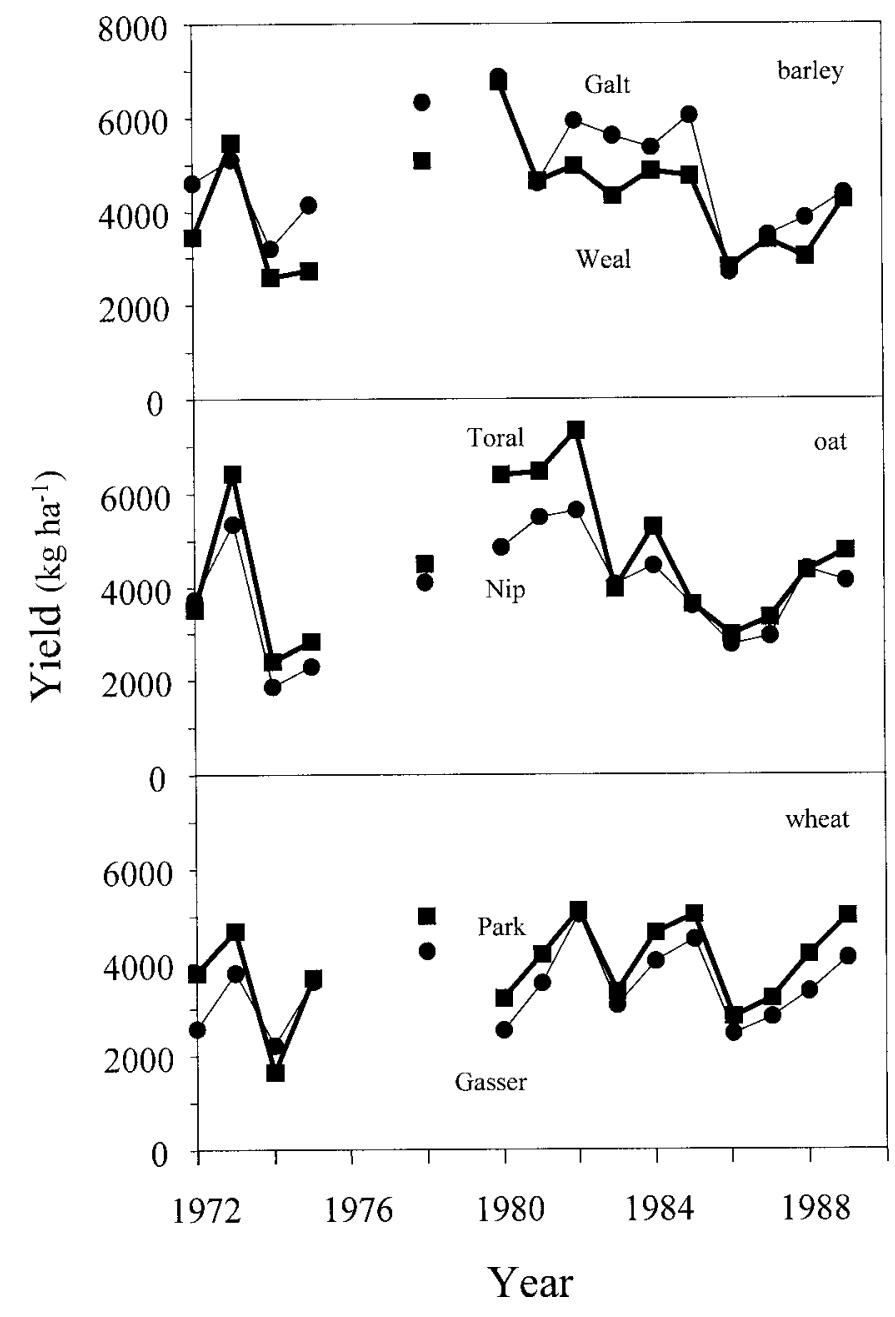

FIG. 1. Grain yield of two cultivars each of barley, oat, and wheat grown over 15 seasons at Fairbanks, Alaska.

low PDR (low pan evaporation or high precipitation). These results are similar to those obtained for barley (greater yield in years with smaller seasonal PE or more precipitation) and suggest that inadequate precipitation or high evaporative demand is the most important factor limiting small grain production. Slope estimates of PDR were not different $(p \leq 0.05)$ between cultivars. These estimates suggest that a decline in the seasonal PDR of 0.1, which represents a decrease in seasonal pan evaporation of $10 \mathrm{~cm}$ or an increase in seasonal precipitation of $4 \mathrm{~cm}$, bolstered yield of Nip and Toral oat by $1175 \mathrm{~kg} \mathrm{ha}^{-1}$.

Oat appeared to be most sensitive to water stresses that occurred during heading and flowering (July) rather than during tillering and stem extension (June). Indeed, the PDR during July, rather than any other monthly climatic factor considered in this study, accounted for the largest percentage of variability in yield of Nip (38\%) and Toral (55\%) oat. Yield was bolstered by low PDR during July (low pan evaporation or high precipitation).

Wheat: Seasonal climatic factors having a significant impact on yield were more numerous for wheat than for oat and barley, including the number of days between precipi- tation events, precipitation deficit, and minimum air temperature. The association between yield of Gasser and Park wheat and these climatic factors can be expressed as:

Gasser: Yield $=6632-33 \times$ DAYS $_{\max }-127 \times \mathrm{PD}+261 \times \mathrm{T}_{\min }$

Park: Yield $=7392-35 \times$ DAYS $_{\max }-159 \times \mathrm{PD}+364 \times \mathrm{T}_{\min }$

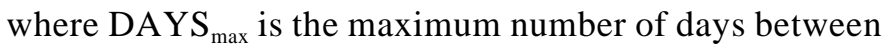
precipitation events and $\mathrm{T}_{\min }$ is the daily minimum air temperature $\left({ }^{\circ} \mathrm{C}\right)$ during the growing season. These factors accounted for $70 \%$ of the variability in Gasser and Park wheat. Slope estimates of each factor in this study were not different $(p \leq 0.05)$ between cultivars. More frequent or greater precipitation or lower pan evaporation during the growing season appeared to bolster yield of wheat, as did higher seasonal minimum air temperatures. The relationships expressed by Equations 5 and 6 suggested that yield of wheat was bolstered about $300 \mathrm{~kg} \mathrm{ha}^{-1}$ when the longest period of drought during the season was reduced by 10 days (the longest period of drought within a growing season ranged from 20 to 71 days across years). This same yield increase was achieved as a result of reducing the seasonal PD by $2 \mathrm{~cm}$ (decreasing seasonal PE or increasing seasonal precipitation by $2 \mathrm{~cm}$ ) or increasing the seasonal minimum air temperature by $1^{\circ} \mathrm{C}$. An increase in the minimum or nighttime air temperature may have a positive influence on yield in this study because growth responses are limited at low temperatures. The lowest temperature in the range of seasonal minimum air temperatures encountered in this study $\left(5.5^{\circ}\right.$ to $\left.9.0^{\circ} \mathrm{C}\right)$ is near the lower threshold for growth processes in wheat (Nuttonson, 1955).

Climatic stresses occurring during heading and flowering (July) influenced wheat yield more than those occurring during tillering and stem extension (June). Indeed, yield of wheat appears more sensitive to water stress near the time of heading and flowering than during any other developmental stage (Wardlaw, 1971; Campbell and Davidson, 1979; Gusta and Chen, 1987). Our finding, however, appears contrary to those from other regions in the Subarctic. Kontturi (1979), for example, reported that precipitation during June was the most important climatic factor (compared with air temperature and global radiation) in wheat production in southern Finland (latitude about $61^{\circ} \mathrm{N}$ ). While latitudinal differences are small between southern Finland and interior Alaska, the maritime climate appears to accentuate the occurrence of drought during June in southern Finland (Konturri, 1979). Vaganov (1990) also reported that yield of spring wheat in the Krasnoyarsk Territory of central Russia (about $56^{\circ} \mathrm{N}$ latitude) was influenced more by climatic stresses occurring in June rather than in May and July. Specifically, greater precipitation or a lower moisture deficit during June resulted in higher yield in the Krasnoyarsk Territory. This region of Russia, however, is drier than interior Alaska, particularly during winter. Spring wheat may be more sensitive to water stress earlier in the growing season 
in the Krasnoyarsk Territory as compared to interior Alaska because soil water reserves at the start of the growing season may be lower in central Russia than in Alaska. In this study, precipitation (specifically the number of days with precipitation) in July had a positive influence on yield. Although the number of days with precipitation accounted for the greatest percentage of variation in yield, this factor explained only $15 \%$ of the variability in yield for Gasser wheat and 24\% for Park wheat.

\section{CONCLUSIONS}

Crop diversity and production in the Subarctic is intuitively constrained by a short, cool growing season. Other climatic factors, perhaps less apparent but still important, may also influence the production of small grains within any given year. For the cultivars examined in this study, crop water stress associated with inadequate or infrequent precipitation or high evaporative demand was the most important factor influencing the interannual variation in grain production. Daily minimum or nighttime temperatures were also found to be suboptimal for wheat production.

Our inability to moderate weather, along with the importance of crop water stress in regulating crop production, warrants the use or development of management practices that conserve soil water in interior Alaska. These practices should be designed not only to store winter precipitation more efficiently and reduce soil evaporation, but also to enhance warming of the soil and circumvent low-temperature stress.

\section{REFERENCES}

ALLEN, L.D. 1983. Climatic conditions. In: McNicholas, H.L., ed. Alaska's agriculture and forestry. Alaska Rural Development Council Publication No. 3. Fairbanks: Cooperative Extension Service, University of Alaska. 29-47.

BRISTOW, K.L., and CAMPBELL, G.S. 1984. On the relationship between incoming solar radiation and daily maximum and minimum temperature. Agriculture Forest Meteorology 31: 159-166.

CAMPBELL, C.A., and DAVIDSON, H.R. 1979. Effect of temperature, nitrogen fertilization and moisture stress on yield, yield components, protein content and moisture use efficiency of Manitou spring wheat. Canadian Journal of Plant Science 59: 963-974.

DOFING, S.M., and KARLSSON, M.G. 1993. Growth and development of uniculm and conventional-tillering barley lines. Agronomy Journal 85:58-61.

DOFING, S.M., and KNIGHT, C.W. 2001. Registration of 'Finaska' barley. Crop Science 41:1993.

DONATELLI, M., and BELLOCCHI, G. 2000. A new method to estimate daily global solar radiation. Proceedings of the $3 \mathrm{rd}$ Crop Science Congress, Hamburg, Germany. 186.
EPPS, A.C., and KERN, E.D. 1983. Agricultural lands. In: McNicholas, H.L., ed. Alaska's agriculture and forestry. Alaska Rural Development Council Publication No. 3. Fairbanks: Cooperative Extension Service, University of Alaska. 13-16.

GABLER, R.E., SAGER, R.J., WISE, D.L., and PETERSEN, J.F. 1999. Essentials of physical geography, 6th ed. Florence, Kentucky: Harcourt College Publishers.

GOODIN, D.G., HUTCHINSON, J.M.S., VANDERLIP, R.L., and KNAPP, M.C. 1999. Estimating solar irradiance for crop modeling using daily air temperature data. Agronomy Journal 91:845-851.

GUSTA, L.V., and CHEN, T.H.H. 1987. The physiology of water and temperature stress. In: Heyne, E.G., ed. Wheat and wheat improvement. 2nd ed. ASA Agronomy Monograph No. 13. Madison, Wisconsin: American Society of Agronomy. 115-150.

JAKOVLEV, N.N. 1973. Agrometeorological factors influencing spring wheat yield and grain quality in the Union of Soviet Socialist Republics. In: Slayter, R.V., ed. Plant response to climatic factors. Proceedings of the Uppsala Symposium, UNESCO (Ecology and Conservation 5). 435-439.

JENSEN, M.E., BURMAN, R.D., and ALLEN, R.G. 1990. Evapotranspiration and irrigation water requirements. New York: American Society of Civil Engineers. 332 p.

KNIGHT, C.W., WOODING, F.J., and LEWIS, C.E. 1978. Relationships between temperature and wheat adaptation in Alaska. Agronomy Abstracts:11.

KONTTURI, M. 1979. The effect of weather on yield and development of spring wheat in Finland. Annales Agriculturae Fenniae 18:263-274.

LEWIS, C.E., and PEARSON, R.W. 1998. Alaska's agriculture: Examining 100 years of growth, lean times. Agroborealis 30: $32-37$.

LUND, R.E. 1989. MSUSTAT statistical software package. Bozeman, Montana: Research and Development Institute, Montana State University.

MOSHCHENKO, Y.B., andZAGREBEL'NYY, V.Y. 1984. Factors responsible for high and reliable yields of spring wheat grown on chernozems in western Siberia. Soviet Soil Science 16(2): $117-123$.

NURMINIEMI, M., and ROGNLI, O.A. 1996. Regression analysis of yield stability is strongly affected by companion test varieties and locations: Examples from a study of Nordic barley lines. Theoretical Applied Genetics 93:468-476.

NUTTONSON, M.Y. 1955. Wheat-climate relationships and the use of phenology in ascertaining the thermal and photothermal requirements of wheat. Washington, D.C.: American Institute of Crop Ecology. 388 p.

PELTONEN, J., KARVONEN, T., and KIVI, E. 1990. The effect of climatic factors on production of spring wheat quantity to quality ratio in southern Finland. Journal of Agriculture Science in Finland 62:227-236.

SHARRATT, B.S. 1994. Observations and modeling of interactions between barley yield and evapotranspiration in the Subarctic. Agricultural Water Management 25:109-119.

. 1998. Barley yield and evapotranspiration governed by tillage practices in interior Alaska. Soil Tillage Research 46: $225-229$. 
1999. Thermal requirements for barley maturation and leaf development in interior Alaska. Field Crops Research 63: 179-184.

TAYLOR, R.L. 1983. Grain crops. In: McNicholas, H.L., ed. Alaska's agriculture and forestry. Alaska Rural Development Council Publication No. 3. Fairbanks: Cooperative Extension Service, University of Alaska. 79-81.

VAGANOV, E.A. 1990. Method of forecasting grain yields with the aid of dendrochronological data. Soviet Journal of Ecology 20(3):139-146.
WARDLAW, I.F. 1971. The early stages of grain development in wheat: Response to water stress in a single variety. Australian Journal of Biological Science 24:1047-1055.

WOODING, F.J. 1998. Rampart Agricultural Experiment Station, 1900-1925: Looking at the past. Agroborealis 30:12-15.

WOODING, F., and McBEATH, J. 1984. Growing winter grains in Alaska. Agroborealis 16:21-26. 